\title{
A Noninvasive, Sensitive, Specific, and Reliable Approach to Assess Whole-Body Nitric Oxide Synthesis in Children
}

\author{
PABLO FORTE, MALCOLM R. OGBORN, AND TANYA LILLEY-CHAN
}

\author{
Department of Pharmacology and Therapeutics [P.F.], University of Manitoba, R3E OT6 Winnipeg, Manitoba, Canada; The Manitoba \\ Institute of Child Health [P.F., M.R.O., T.L.-C.], R3E 3P4 Winnipeg, Manitoba, Canada
}

\begin{abstract}
Determination of nitric oxide (NO) synthesis in vivo is essential to understand the pathophysiologic role and therapeutic implications of the L-arginine/NO pathway in pediatric diseases. The aim of this study was to establish a noninvasive, sensitive, specific, and reliable approach to determine whole-body NO synthesis in healthy children. Seventeen healthy children (eight boys/nine girls, 4-16 y) were studied twice, and six of them on three occasions. Fasting children received a single oral dose of nonradioactive $\mathrm{L}-\left[{ }^{15} \mathrm{~N}\right]_{2}$-guanidino arginine $(5 \mathrm{mg} / \mathrm{kg}$ body weight). Complete $24-\mathrm{h}$ urine collections were subsequently performed on an ambulatory basis. Total urinary nitrate excretion and $\left[{ }^{15} \mathrm{~N}\right]$ nitrate enrichments were determined using high-pressure liquid chromatography and gas chromatography-isotope ratio mass spectrometric techniques. The mean urinary $\left[{ }^{15} \mathrm{~N}\right]$ nitrate enrichments on the $0-12-\mathrm{h} / 12-24-\mathrm{h}$ collection periods of three study visits were $0.9309 \% / 0.5910 \%$, $0.9056 \% / 0.6214 \%$, and $0.9087 \% / 0.6059 \%$. The levels of 24 -h urinary $\left[{ }^{15} \mathrm{~N}\right]$ nitrate excretion [mean $(95 \%$ confidence interval)] for three study visits were 11.70 (8.85-14.54), 12.21 (9.61-14.82), and 11.37 (7.96-14.77) $\mu \mathrm{g}\left[{ }^{15} \mathrm{~N}\right]$ nitrogen-nitrate/mmol creatinine, respectively. Within-subject coefficient of variation for 24-h urinary $\left[{ }^{15} \mathrm{~N}\right]$ nitrate excretion was $11.87 \%$. Agreement among results was assessed by intraclass correlation coefficient (0.93) and coefficient of repeatability (4.08). The percentage of $\mathrm{L}^{-}\left[{ }^{15} \mathrm{~N}\right]_{2}$-guanidino arginine dose directed to nitric oxide synthesis was $0.221 \%$ [0.181-0.261]. Multiple regression analysis showed age as the predictor variable of whole-body NO synthesis. These results show for the first time that a single oral administration of $\mathrm{L}_{-}\left[{ }^{15} \mathrm{~N}\right]_{2}$-guanidino arginine can be used to reliably and specifically determine whole-body NO synthesis in children. (Pediatr Res 59: 736-741, 2006)
\end{abstract}

$\mathrm{T}$ he L-arginine/NO pathway has been an exciting research area for the past two decades. NO is endogenously synthesized from the amino acid L-arginine by NO synthase (NOS) in numerous cells, including platelets, neurons, macrophages, and endothelial cells (1). Three isoforms of human NOS have been cloned: neuronal, endothelial, and inducible (2). Both the neuronal NOS and endothelial NOS are constitutively expressed in cells and produce picomolar amounts of

Received September 21, 2005; accepted December 19, 2005.

Correspondence: Pablo Forte, M.D., Ph.D., University of Manitoba, Department of Pharmacology and Therapeutics, 753 McDermott Avenue, Chown Building, Room A410, Winnipeg R3E OT6, Manitoba, Canada, e-mail: pforte@cc.umanitoba.ca, forte_pablo@yahoo.ca

This study was supported by a start-up grant from the Department of Pharmacology and Therapeutics, Faculty of Medicine, University of Manitoba, and small grants from The Manitoba Institute of Child Health and The University of Manitoba Research Grant Committee.

DOI: $10.1203 / 01 . p d r .0000214880 .15623 .84$
NO. By contrast, the inducible isoform produces high and sustained levels of NO and is usually expressed in macrophages and vascular smooth muscle cells following the exposure to cytokines and lipopolysaccharide (3). The physiologic importance of the L-arginine/NO pathway has been extensively studied in humans. It is known to play a major role in controlling vascular tone, platelet function, neurotransmission, and bronchial airway reactivity $(1,4)$.

Basic research on NO derived from in vitro and in vivo experimental models has started to have an impact on pediatrics. Accumulating evidence suggest that the NO signaling pathway is abnormal in a number of pediatric conditions including primary pulmonary hypertension (5), childhood essential hypertension (6), and cerebral malaria (7) and markedly increased in others such as septic shock (8), gastroenteritis $(9,10)$, bronchial asthma (11), type 1 diabetes mellitus (12), and autoimmune and inflammatory diseases (13). Accurate and reliable determination of NO synthesis in vivo is essential to understand the pathophysiologic and therapeutic roles of this biologic pathway. Direct measurement of exhaled $\mathrm{NO}$ is a noninvasive and practical approach for assessing airway inflammation in children (14). Indeed, exhaled NO has been proposed as a tool for screening and monitoring airway inflammation and titration of anti-inflammatory therapy in asthmatic children (15). On the other hand, determination of systemic NO synthesis has been proved difficult because of NO's short plasma half-life (3-5 s) (16). This limitation has led to the development of functional and chemical markers to determine NO bioactivity. Biomarkers such as cyclic guanosine monophosphate, L-citrulline, and nitrate concentrations in plasma and urine have been used in clinical studies to assess systemic NO synthesis. However, these metabolites are not specific for the L-arginine/NO pathway (17). An approach to assess whole-body $\mathrm{NO}$ synthesis in critically ill children (i.e. septic shock) consists of a primed, 5-8-h constant i.v. infusion of $\mathrm{L}-\left[{ }^{15} \mathrm{~N}\right]_{2}$-guanidino arginine, and collection of

\footnotetext{
Abbreviations: BSA, body surface area; $\mathbf{M S}_{\mathbf{W}}$, mean sum of squares withinsubjects; $\mathbf{M S}_{\mathbf{B}}$, mean sum of squares between subjects; atom\%, atom percent
} 
multiple blood and urine samples at pharmacokinetic steadystate conditions for determination of isotopic enrichments of $\mathrm{L}-\left[{ }^{15} \mathrm{~N}\right]_{2}$-guanidino arginine, L- $\left[{ }^{15} \mathrm{~N}\right]$-ureido citrulline, and $\left[{ }^{15} \mathrm{~N}\right]$ nitrate $(5,18)$. However, the invasive nature of this approach raises ethical issues and precludes its applicability to healthy children (18). In addition, this approach is expensive, complex, time-consuming, and highly affected by dietary nitrate intake, which is not suitable for studies with large numbers of children.

The aim of our present investigation was to establish a noninvasive, sensitive, specific, and reliable approach to quantify whole-body NO synthesis in children. In humans, NO is synthesized from the guanidino nitrogen atoms of $\mathrm{L}$-arginine by NOS, and this is the only biochemical route by which these nitrogen atoms are incorporated into nitrate (19). Furthermore, nitrate constitutes the major stable oxidation end product of NO, which is primarily excreted through the kidney (16). On the other hand, orally administered L-arginine is avidly and rapidly absorbed by the intestinal brush border membrane, through the $\mathrm{y}^{+}$carrier transporter system for cationic amino acids (20). Moreover, Felig and Wahren (21) reported no significant changes of L-arginine concentration gradient between the portal and hepatic veins in postabsorptive subjects, indicating no net uptake or release of L-arginine by the human liver. Therefore, we tested the hypothesis that a single oral dose administration of $\mathrm{L}_{\mathrm{L}}\left[{ }^{15} \mathrm{~N}\right]_{2}$-guanidino arginine and measurement of urinary $\left[{ }^{15} \mathrm{~N}\right]$ nitrate excretion provide reliable estimates of whole-body NO synthesis in healthy children.

\section{METHODS}

Subjects. This study was approved by the Medical Research Ethics Committee, University of Manitoba, and performed in the John Buhler Research Centre, Winnipeg, Canada. Healthy children were recruited into this study following detailed explanation of the purpose of the research and written informed consent from each child's parents. Children with a history of cardiovascular, allergy, respiratory, neuronal, inflammatory, or renal diseases were excluded from the study. Any child with evidence of viral or urinary infections (verified by urinalysis), nocturnal enuresis, or smoking was also excluded. Blood tests for routine hematology and biochemistry were also performed to ensure that the children were healthy. The children's height and weight were assessed with a calibrated healthometer medical scale.

Tracer study. After a 12-h overnight fast, the subjects rested in the study room for at least 15 min before assessment of blood pressure with an automated oscillatory blood pressure system (Dinamap, Model 1846 SX; Critikon Inc.). Thereafter, the children received a single oral dose of nonradioactive $\mathrm{L}-\left[{ }^{15} \mathrm{~N}\right]_{2}$-guanidino arginine $\left(5 \mathrm{mg} / \mathrm{kg} \mathrm{BW}, 98 \mathrm{~mol} \%\left[{ }^{15} \mathrm{~N}\right]\right.$; Cambridge Isotope Lab, Cambridge, MA) dissolved in $30 \mathrm{~mL}$ distilled water. The solution container was then carefully rinsed three times with $10 \mathrm{~mL}$ of distilled water, and the solution was consumed. Complete 24-h urine collections were subsequently carried out on ambulatory basis using 2-L polypropylene dark bottles, containing $1 \mathrm{~g}$ sodium hydroxide as a preservative for the periods $0-12 \mathrm{~h}$ and $12-24 \mathrm{~h}$. We previously demonstrated the chemical stability of inorganic nitrate in urine samples spiked with sodium hydroxide over a 24 -h period at room temperature $(22,23)$. Parents and children were advised to monitor and comply with urine collection. Urine volumes were measured, and aliquots from each period were frozen at $-80^{\circ} \mathrm{C}$ until analysis. Children followed a limited nitrate diet for $48 \mathrm{~h}$, i.e. for $24 \mathrm{~h}$ before the study visits, and for $24 \mathrm{~h}$ during the course of urine collection. Food with high content of nitrate not allowed included seafood (shellfish, saltwater fish, or freshwater fish); cured, smoked, preserved, canned, or processed meats (bacon, sausage, ham, hot dogs, pepperoni, corned beef, pastrami); canned meats and fish, including tuna; nuts, peanut butter; all vegetables (raw or cooked) including potatoes; and fruits.

Experimental reliability of methodology. Whole-body NO synthesis was assessed on several occasions, at least $2 \mathrm{wk}$ apart, to determine the reliability of this methodological approach. Determination of within-subject coefficient of variation, coefficient of repeatability, and intraclass correlation coefficient were assessed over several consecutive study visits.

Determination of total urinary nitrate excretion. Total urinary nitrate concentration was determined using the Griess reaction as previously described $(22,23)$. The detection limit was $1 \mu \mathrm{mol} / \mathrm{L}$, and the interday coefficient of variation of measured concentrations $(10-150 \mu \mathrm{mol} / \mathrm{L})$ was $<3 \%$.

Determination of urinary $\left[{ }^{15} \mathrm{~N}\right]$ nitrate enrichments. Urinary $\left[{ }^{15} \mathrm{~N}\right]$ nitrate enrichments were assessed using an isotope ratio mass spectrometer (PDZ Europa $20-20, \mathrm{UK})$ as previously reported $(22,23)$. The precision of $\left[{ }^{15} \mathrm{~N}\right] /$ $\left[{ }^{14} \mathrm{~N}\right]$ nitrogen ratio measurements was $\pm 0.0004 \%$. The interday coefficient of variation of urinary $\left[{ }^{15} \mathrm{~N}\right]$ nitrate enrichment analyses ranged from $0.81 \%$ to $0.90 \%$.

Calculations and statistical analysis. Data were expressed as mean (95\% confidence interval), with differences considered statistically significant at the level of $p<0.05$. Statistical data analysis was performed using analysis of variance. Natural logarithmic transformations were applied to data that were not normally distributed. Statistics was conducted using SPSS 12.0 software for Windows (SPSS Inc., Chicago, IL).

Body surface area (BSA) was calculated according to Mosteller's formula (24): $\sqrt{ }$ [weight $(\mathrm{kg}) *$ height $(\mathrm{cm}) / 3600)]$.

Urinary $\left[{ }^{15} \mathrm{~N}\right]$ nitrate enrichment was calculated as follows (25): Atom\% $\left[{ }^{15} \mathrm{~N}\right]=100 /(2 R+1)$, where $R$ is the ratio of ions with $\mathrm{m} / \mathrm{z} 28$ and 29

Urinary $\left[{ }^{15} \mathrm{~N}\right]$ nitrate excretion was assessed by computing 24-h urinary nitrate excretion and the atom\% excess of $\left[{ }^{15} \mathrm{~N}\right]$ nitrate (23):

$$
\text { Urinary }\left[{ }^{15} \mathrm{NO}_{3}\right] \text { excretion }=\frac{\begin{array}{c}
\text { total urinary } \mathrm{NO}_{3} \\
\text { excretion }(\mu \mathrm{g} / \mathrm{mmol} \text { creatinine }) \\
* \text { urinary }\left[{ }^{15} \mathrm{~N}\right] \text { at } \% \text { excess }
\end{array}}{100}
$$

The percentage of $\mathrm{L}_{-}\left[{ }^{15} \mathrm{~N}\right]_{2}$-guanidino arginine dose converted to NO synthesis was assessed (23):

$$
\begin{aligned}
& \% \mathrm{~L}-\left[{ }^{15} \mathrm{~N}\right]_{2} \text { arginine } \rightarrow{ }^{15} \mathrm{NO}=\frac{\begin{array}{c}
24 \mathrm{~h}-\text { urinary }\left[{ }^{15} \mathrm{~N}\right] \\
\text { nitrate excretion }(\mu \mathrm{g})
\end{array}}{\text { oral dose } \mathrm{L}-\left[{ }^{15} \mathrm{~N}\right]_{2} \text {-guanidino }} \times 100 \\
& \text { arginine }(\mu \mathrm{g})
\end{aligned}
$$

Renal function was determined by the creatinine renal clearance corrected for BSA (26):

$\mathrm{Cl}_{\text {creat }}=\left(\mathrm{U}_{\mathrm{cr}} * \mathrm{U}_{\mathrm{vol}} * 1.73\right) /\left(\mathrm{S}_{\mathrm{cr}} * 24 \mathrm{~h} * \mathrm{BSA}\right)$; where $\mathrm{U}_{\mathrm{cr}}$ is urinary creatinine concentration, $\mathrm{U}_{\mathrm{vol}}$ is 24 -h urine volume, and $\mathrm{S}_{\mathrm{cr}}$ is serum creatinine concentration.

The Bland-Altman analysis was conducted to assess the limits of agreement of body NO measurements between study visits (27). Measurement error and reliability of whole-body NO synthesis assessment were determined by the following statistical tests (28):

1. Within-subject coefficient of variation $\left(\mathrm{CV}_{\mathrm{W}}\right)$ was derived from the measurements performed on consecutive study visits and the mean average of the study visits: $\mathrm{CV}_{\mathrm{W}}=\left({ } \mathrm{MS}_{\mathrm{W}} / \mu\right) * 100$, where $\mathrm{MS}_{\mathrm{W}}$ is the mean sum of squares within subjects.

2. Assessment of coefficient of repeatability (RC) was assessed using: $R C$ $=2 \sqrt{ }\left(\Sigma D i^{2} / n\right)$; where $D_{i}$ is the absolute difference between measurements of visits 1 and 2 , and $n$ is number of measurements.

3. The intraclass correlation coefficient (ICC) was assessed by relating within-subject variability to between-subject variability in repeated observations using: ICC $=\left[\mathrm{MS}_{\mathrm{B}}-\mathrm{MS}_{\mathrm{W}}\right] /\left[\mathrm{MS}_{\mathrm{B}}+(n-1) \mathrm{MS}_{\mathrm{W}}\right]$, where $\mathrm{MS}_{\mathrm{B}}$ is mean sum of squares between subjects.

Univariate linear regression analysis was performed to determine the association of percentage conversion of $\mathrm{L}-\left[{ }^{15} \mathrm{~N}\right]_{2}$-guanidino arginine to $\mathrm{NO}$ synthesis with a number of biologic variables (age, gender, blood pressure, and renal creatinine clearance). In addition, stepwise multiple regression analysis was used to estimate the independent relationship between these predictor variables and the percentage conversion of $\mathrm{L}-\left[{ }^{15} \mathrm{~N}\right]_{2}$-guanidino arginine to NO synthesis.

\section{RESULTS}

Subjects. The total population studied was 17 healthy children (eight boys/nine girls), ages 4 to $16 \mathrm{y}$ and between the 25th and 75th percentiles for weight and height. Children were of white race except for a Métis girl and an AboriginalCanadian girl. All subjects participated in the study twice, and six of them on three occasions. The study protocol was safe 
and well accepted by both the children and their parents. The study population characteristics are presented in Table 1 .

Experimental reliability of methodology. The $\left[{ }^{15} \mathrm{~N}\right]$ isotopic enrichments and amounts of urinary $\left[{ }^{15} \mathrm{~N}\right]$ nitrate [mean (95\% confidence interval)] excreted after the administration of $\mathrm{L}-\left[{ }^{15} \mathrm{~N}\right]_{2}$-guanidino arginine are shown in Table 2 . The mean urinary $\left[{ }^{15} \mathrm{~N}\right]$ nitrate enrichments on the $0-12-\mathrm{h} / 12-24-\mathrm{h}$ collection periods of three study visits were $0.9309 \% / 0.5910 \%$, $0.9056 \% / 0.6214 \%$, and $0.9087 \% / 0.6059 \%$. The levels of $24-\mathrm{h}$ urinary $\left[{ }^{15} \mathrm{~N}\right]$ nitrate excretion for these visits were 11.70 (8.85-14.54), 12.21 (9.61-14.82), 11.37 (7.96-14.77) $\mu \mathrm{g}$ $\left[{ }^{15} \mathrm{~N}\right]$ nitrogen-nitrate/mmol creatinine, respectively. There was no significant differences of 24 -h urinary $\left[{ }^{15} \mathrm{~N}\right]$ nitrate excretion levels between study visits $(p=0.79)$. To visualize the repeatability of individual measurements, we plotted the absolute difference of repeated measurements performed by all children (visit 1 - visit 2) against their means (Fig. 1). The bias $\pm \mathrm{SD}$ of the measurement differences was $-0.16 \pm 2.04$ $\mu \mathrm{g}\left[{ }^{15} \mathrm{~N}\right]$ nitrogen-nitrate/mmol creatinine $(95 \%$ limits of agreement: -4.16 to 3.83 ). Within-subject coefficient of variation for $24-\mathrm{h}$ urinary $\left[{ }^{15} \mathrm{~N}\right]$ nitrate excretion was $11.87 \%$. Agreement among the results was evaluated by the determination of intraclass correlation coefficient (0.93) and coefficient of repeatability (4.08).

Determinants of whole-body NO synthesis in healthy children. There was no correlation between $24-\mathrm{h}$ urinary $\left[{ }^{15} \mathrm{~N}\right] \mathrm{ni}$ trate excretion and renal creatinine clearance $(r=0.05, p=$ $0.78)$. The percentage of $\mathrm{L}_{\mathrm{L}}\left[{ }^{15} \mathrm{~N}\right]_{2}$-guanidino arginine dose directed to NO synthesis at each study visit was $0.220 \%$ $(0.179-0.260], 0.225 \%(0.184-0.265)$, and $0.220 \%(0.142-$ $0.299)$, respectively. The average percentage of $\mathrm{L}_{-}\left[{ }^{15} \mathrm{~N}\right]_{2}-$ guanidino arginine converted to NO synthesis at all study visits was $0.221 \%(0.181-0.261)$; (range $0.119 \%-0.411 \%$ ). There was a trend toward an inverse correlation between mean arterial blood pressure and whole-body NO synthesis $(r=$ $-0.25, p=0.32$ ). Univariate regression analysis revealed a significant inverse correlation between age and percentage conversion of $\mathrm{L}-\left[{ }^{15} \mathrm{~N}\right]_{2}$-guanidino arginine to NO synthesis $(r$
$=-0.53, p<0.05$, Fig. 2). The levels of 24-h urinary $\left[{ }^{15} \mathrm{~N}\right]$ nitrate excretion were also inversely correlated with age $(r=-0.47, p=0.027)$. The percentage conversion of $\mathrm{L}-\left[{ }^{15} \mathrm{~N}\right]_{2}$-guanidino arginine to NO synthesis was higher in girls than in boys: $0.260 \%(0.203-0.326)$ versus $0.176 \%$ $(0.150-0.202)(p=0.03)$. However, stepwise multiple regression analysis showed age as the only predictor variable of the percentage conversion of $\mathrm{L}-\left[{ }^{15} \mathrm{~N}\right]_{2}$-guanidino arginine to NO synthesis $(r=-0.48, p=0.016)$.

\section{DISCUSSION}

This study has shown that a single oral administration of nonradioactive L- $\left[{ }^{15} \mathrm{~N}\right]_{2}$-guanidino arginine can be used to reliably assess whole-body NO synthesis in healthy children aged 4 to $16 \mathrm{y}$. The amount of $\left[{ }^{15} \mathrm{~N}\right]$ nitrate excreted in urine after the administration of $\mathrm{L}-\left[{ }^{15} \mathrm{~N}\right]_{2}$-guanidino arginine has the advantage of being both quantitative and specific for the L-arginine/NO pathway.

We have previously reported using a single i.v. dose of $\mathrm{L}-\left[{ }^{15} \mathrm{~N}\right]_{2}$-guanidino arginine that $0.138 \%-0.172 \%$ of the systemic L-arginine pool is metabolized to NO synthesis in healthy adults $(22,23,29-31)$. In this study, we found that the mean percentage of $\mathrm{L}-\left[{ }^{15} \mathrm{~N}\right]_{2}$-guanidino arginine directed to $\left[{ }^{15} \mathrm{~N}\right] \mathrm{NO}$ synthesis was $0.221 \%$. This surprisingly increased transfer of $\left[{ }^{15} \mathrm{~N}\right]$ from L-arginine to NO in comparison with our data for adults are unclear. However, Castillo et al. (32) reported in young healthy adults $(18-24$ y) evidence of $\left[{ }^{15} \mathrm{~N}\right]$ nitrate formation within the splanchnic region, since equal amounts of i.v. and intragastric continuous infusions of $\mathrm{L}-\left[{ }^{15} \mathrm{~N}\right]_{2}$-guanidino arginine resulted in different degrees of urinary $\left[{ }^{15} \mathrm{~N}\right]$ nitrate enrichments. The authors estimated that approximately $16 \%$ of daily endogenous nitrate synthesis comes from the metabolism of dietary L-arginine to NO within the splanchnic region. It is also interesting to note that in their study the percentage of continuous intragastric $\mathrm{L}_{-}\left[{ }^{15} \mathrm{~N}\right]_{2}$ guanidino arginine dose recovered as urinary $\left[{ }^{15} \mathrm{~N}\right]$ nitrate was $0.4 \%$ (32), which is within the range of our present estimates

Table 1. Clinical characteristics of healthy children

\begin{tabular}{|c|c|c|c|c|c|c|c|c|c|c|}
\hline Child No. & $\begin{array}{l}\text { Age } \\
(\mathrm{y})\end{array}$ & Gender & Race & $\begin{array}{c}\text { Weight } \\
(\mathrm{kg})\end{array}$ & $\begin{array}{l}\text { Height } \\
(\mathrm{m})\end{array}$ & $\begin{array}{l}\text { BSA } \\
\left(\mathrm{m}^{2}\right)\end{array}$ & $\begin{array}{l}\text { Creatinine clearance } \\
\left(\mathrm{ml} / \mathrm{min} / 1.73 * \mathrm{~m}^{2}\right)\end{array}$ & $\begin{array}{c}\text { Systolic BP } \\
(\mathrm{mm} \mathrm{Hg})\end{array}$ & $\begin{array}{c}\text { Diastolic BP } \\
(\mathrm{mm} \mathrm{Hg})\end{array}$ & $\begin{array}{l}\text { S-Cholesterol } \\
(\mathrm{mmol} / \mathrm{L})\end{array}$ \\
\hline 1 & 16 & $\mathrm{M}$ & White & 62.8 & 1.65 & 1.70 & 130 & 110 & 53 & 2.90 \\
\hline 2 & 10 & M & White & 38.3 & 1.43 & 1.23 & 100 & 121 & 55 & 3.53 \\
\hline 3 & 7 & $\mathrm{~F}$ & White & 25.0 & 1.21 & 0.91 & 111 & 133 & 63 & 3.81 \\
\hline 4 & 15 & M & White & 62.0 & 1.79 & 1.76 & 129 & 137 & 68 & 3.28 \\
\hline 5 & 12 & M & White & 45.0 & 1.59 & 1.41 & 103 & 127 & 73 & 4.05 \\
\hline 6 & 5 & M & White & 18.3 & 1.09 & 0.74 & 104 & 105 & 59 & 4.02 \\
\hline 7 & 6 & $\mathrm{~F}$ & White & 24.4 & 1.19 & 0.90 & 95 & 98 & 74 & 4.12 \\
\hline 8 & 12 & M & White & 54.0 & 1.53 & 1.51 & 131 & 112 & 63 & 4.10 \\
\hline 9 & 11 & $\mathrm{~F}$ & Métis & 47.0 & 1.59 & 1.44 & 119 & 116 & 70 & 3.34 \\
\hline 10 & 4 & $\mathrm{~F}$ & A & 17.6 & 1.16 & 0.75 & 118 & 100 & 52 & 3.39 \\
\hline 11 & 5 & M & White & 20.6 & 1.17 & 0.93 & 108 & 115 & 62 & 3.71 \\
\hline 12 & 10 & M & White & 34.1 & 1.47 & 1.18 & 97 & 105 & 65 & 3.77 \\
\hline 13 & 7 & $\mathrm{~F}$ & White & 23.0 & 1.19 & 0.87 & 92 & 99 & 68 & 3.88 \\
\hline 14 & 11 & $\mathrm{~F}$ & White & 29.7 & 1.32 & 1.04 & 115 & 114 & 68 & 3.49 \\
\hline 15 & 16 & $\mathrm{~F}$ & White & 60.1 & 1.68 & 1.67 & 118 & 126 & 70 & 3.72 \\
\hline 16 & 8 & $\mathrm{~F}$ & White & 27.4 & 1.34 & 1.01 & 102 & 94 & 55 & 3.23 \\
\hline 17 & 10 & $\mathrm{~F}$ & White & 34.5 & 1.44 & 1.17 & 104 & 94 & 50 & 2.78 \\
\hline
\end{tabular}

A, Aboriginal-Canadian; BP, blood pressure. 
Table 2. Urinary $\left[{ }^{15} \mathrm{~N}\right]$ nitrate excretion and percentage conversion of $\mathrm{L}_{\mathrm{-}}\left[{ }^{15} \mathrm{~N}\right]_{2}$-guanidino arginine to $\left[{ }^{15} \mathrm{~N}\right]$ nitrate in healthy children on different study visits

\begin{tabular}{|c|c|c|c|c|c|}
\hline \multicolumn{6}{|c|}{ First study visit } \\
\hline Child No. & $\begin{array}{c}24 \mathrm{~h} \mathrm{NO}_{3} * \\
\text { ( } \mu \mathrm{g} \text { nitrogen) }\end{array}$ & $\begin{array}{c}{ }^{15} \mathrm{NO}_{3}(0-12 \mathrm{~h}) \dagger \\
\quad \text { atom \%) }\end{array}$ & $\begin{array}{c}{ }^{15} \mathrm{NO}_{3}(12-24 \mathrm{~h}) \dagger \\
(\text { atom \%) }\end{array}$ & $\begin{array}{c}\text { Total }{ }^{15} \mathrm{NO}_{3} \ddagger \\
\left(\mu \mathrm{g}{ }^{15} \mathrm{~N} / \mathrm{mmol} \text { creat }\right)\end{array}$ & $\begin{array}{c}\% \text { conversion } \S \\
\left({ }^{15} \mathrm{~N} \mathrm{Arf} \rightarrow{ }^{15} \mathrm{NO}_{3}\right)\end{array}$ \\
\hline 2 & 6815.93 & 1.0551 & 0.6480 & 10.72 & 0.187 \\
\hline 3 & 9242.65 & 1.0163 & 0.5648 & 19.25 & 0.424 \\
\hline 4 & 8228.65 & 1.1168 & 0.7235 & 6.58 & 0.188 \\
\hline 7 & 9553.77 & 0.7972 & 0.5108 & 22.88 & 0.313 \\
\hline 8 & 7766.53 & 1.0249 & 0.5736 & 8.05 & 0.140 \\
\hline 9 & 8354.52 & 0.7029 & 0.4927 & 3.38 & 0.149 \\
\hline 10 & 5150.20 & 0.9243 & 0.4433 & 8.79 & 0.272 \\
\hline 11 & 6949.55 & 0.8270 & 0.5100 & 8.51 & 0.236 \\
\hline 12 & 5494.02 & 0.7864 & 0.5478 & 13.97 & 0.128 \\
\hline $\begin{array}{l}\text { Mean } \\
95 \% \text { CI }\end{array}$ & $\begin{array}{c}6998.33 \\
(6180.43 .7815 .76)\end{array}$ & $\begin{array}{c}0.9309 \\
(0.8626,0.9992)\end{array}$ & $\begin{array}{c}0.5910 \\
(0.5466,0.6355)\end{array}$ & $\begin{array}{c}11.70 \\
(8.85,14.54)\end{array}$ & $\begin{array}{c}0.220 \\
(0.179,0.260)\end{array}$ \\
\hline
\end{tabular}

Second study visit

\begin{tabular}{|c|c|c|c|c|c|}
\hline Child No. & $\begin{array}{c}24 \mathrm{~h} \mathrm{NO}_{3} * \\
(\mu \mathrm{g} \text { nitrogen })\end{array}$ & $\begin{array}{c}{ }^{15} \mathrm{NO}_{3}(0-12 \mathrm{~h}) \dagger \\
(\text { atom \%) } \\
\end{array}$ & $\begin{array}{c}{ }^{15} \mathrm{NO}_{3}(12-24 \mathrm{~h}) \dagger \\
(\text { atom } \%)\end{array}$ & $\begin{array}{c}\text { Total }{ }^{15} \mathrm{NO}_{3} \ddagger \\
\left(\mu \mathrm{g}{ }^{15} \mathrm{~N} / \mathrm{mmol} \text { creat }\right)\end{array}$ & $\begin{array}{c}\% \text { conversion } \S \\
\left({ }^{15} \mathrm{~N} \mathrm{Arg} \rightarrow{ }^{15} \mathrm{NO}_{3}\right)\end{array}$ \\
\hline 1 & 10819.96 & 0.9102 & 0.8366 & 7.12 & 0.170 \\
\hline 2 & 8235.69 & 0.8766 & 0.5627 & 9.02 & 0.181 \\
\hline 4 & 8968.22 & 1.1346 & 0.7498 & 8.43 & 0.195 \\
\hline 5 & 7368.28 & 0.9221 & 0.7308 & 7.41 & 0.187 \\
\hline 6 & 4986.09 & 0.8225 & 0.5172 & 15.40 & 0.170 \\
\hline 9 & 10807.71 & 0.7474 & 0.6064 & 5.08 & 0.139 \\
\hline 10 & 6712.60 & 0.8852 & 0.4951 & 12.08 & 0.339 \\
\hline 11 & 9021.97 & 0.7471 & 0.5938 & 10.85 & 0.261 \\
\hline 12 & 4733.37 & 0.7721 & 0.5786 & 12.42 & 0.116 \\
\hline 13 & 7140.10 & 0.9736 & 0.5837 & 22.97 & 0.314 \\
\hline 14 & 5039.93 & 1.0706 & 0.5752 & 17.28 & 0.212 \\
\hline $\begin{array}{l}\text { Mean } \\
95 \% \text { CI }\end{array}$ & $\begin{array}{c}7932.33 \\
(6966.85,8898.15)\end{array}$ & $\begin{array}{c}0.9056 \\
(0.8498,0.9614)\end{array}$ & $\begin{array}{c}0.6214 \\
(0.5731,0.6697)\end{array}$ & $\begin{array}{c}12.21 \\
(9.61,14.82)\end{array}$ & $\begin{array}{c}0.225 \\
(0.184,0.265)\end{array}$ \\
\hline \multicolumn{6}{|c|}{ Third study visit } \\
\hline Child No. & $\begin{array}{c}24 \mathrm{~h} \mathrm{NO}_{3}{ }^{*} \\
(\mu \mathrm{g} \text { nitrogen })\end{array}$ & $\begin{array}{c}{ }^{15} \mathrm{NO}_{3}(0-12 \mathrm{~h}) \dagger \\
(\text { atom \%) }\end{array}$ & $\begin{array}{c}{ }^{15} \mathrm{NO}_{3}(12-24 \mathrm{~h}) \dagger \\
(\text { atom \%) }\end{array}$ & $\begin{array}{c}\text { Total }{ }^{15} \mathrm{NO}_{3} \ddagger \\
\left(\mu \mathrm{g}{ }^{15} \mathrm{~N} / \mathrm{mmol} \text { creat }\right)\end{array}$ & $\begin{array}{c}\% \text { conversion } \S \\
\left({ }^{15} \mathrm{~N} \mathrm{Arg} \rightarrow{ }^{15} \mathrm{NO}_{3}\right)\end{array}$ \\
\hline 1 & 9181.49 & 0.9624 & 0.5252 & 6.71 & 0.167 \\
\hline 2 & 10758.31 & 0.7516 & 0.5598 & 11.98 & 0.179 \\
\hline 3 & 9928.33 & 0.9043 & 0.6200 & 17.69 & 0.419 \\
\hline 4 & 10375.49 & 0.9640 & 0.7939 & 8.31 & 0.196 \\
\hline 5 & 7309.40 & 1.1130 & 0.6383 & 8.68 & 0.188 \\
\hline 6 & 5958.48 & 0.7568 & 0.4981 & 14.82 & 0.172 \\
\hline
\end{tabular}

* Twenty-four-hour total urinary nitrate excretion presented as $\mu \mathrm{g}$ nitrogen.

$\dagger$ Atom percent $\left[{ }^{15} \mathrm{~N}\right]$ enrichment of urinary nitrate.

$\ddagger$ Twenty-four-hour urinary $\left[{ }^{15} \mathrm{~N}\right]$ nitrate excretion presented as $\mu \mathrm{g}\left[{ }^{15} \mathrm{~N}\right]$ nitrogen per mmol urinary creatinine.

$\S$ Percentage conversion of $\mathrm{L}-\left[{ }^{15} \mathrm{~N}\right]_{2}$-guanidino arginine to NO. 


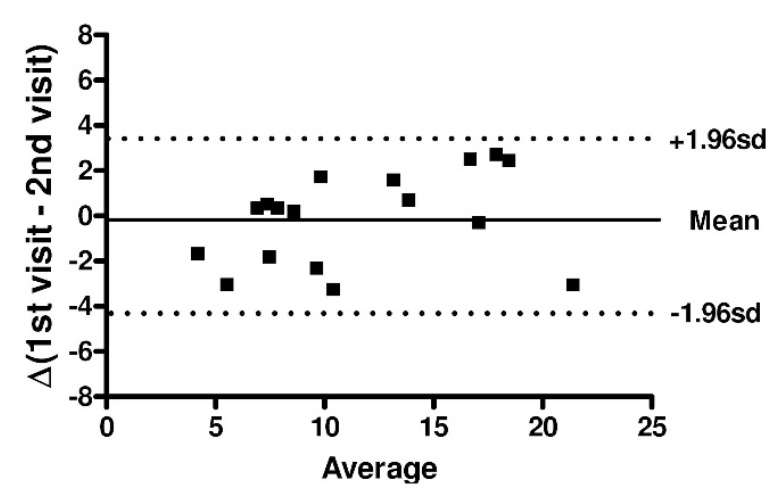

Figure 1. A Bland-Altman plot shows the differences of repeated measurements of whole-body NO synthesis in healthy children. There was no significant differences of 24-h urinary $\left[{ }^{15} \mathrm{~N}\right]$ nitrate excretion levels between study visits $(n=17, p=0.79)$. The bias of the measurement differences was $-0.16 \mu \mathrm{g}\left[{ }^{15} \mathrm{~N}\right]$ nitrogen-nitrate/mmol urinary creatinine $(95 \%$ limits of agreement: -4.16 to 3.83 ). The coefficient of repeatability was 4.08 .

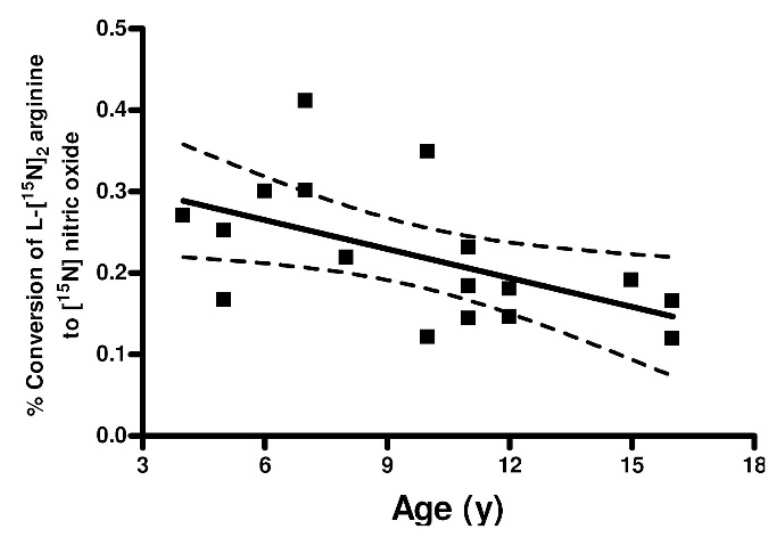

Figure 2. Linear regression analysis with $95 \%$ confidence intervals for the association between age and percentage conversion of $\mathrm{L}-\left[{ }^{15} \mathrm{~N}\right]_{2}$-guanidino arginine to NO synthesis in healthy children $(r=-0.53, n=17, p<0.05)$.

$(0.119 \%-0.411 \%)$. In our study, we have assumed that, in fasting conditions, orally administered $\mathrm{L}-\left[{ }^{15} \mathrm{~N}\right]_{2}$-guanidino arginine was completely absorbed from the gastrointestinal tract. Indeed, a previous study with healthy young volunteers showed that $38 \%$ of an oral dose $\mathrm{L}-\left[{ }^{15} \mathrm{~N}\right]_{2}$-guanidino arginine was absorbed and metabolized within the splanchnic region, and the remaining $62 \%$ of $\mathrm{L}_{-}\left[{ }^{15} \mathrm{~N}\right]_{2}$-guanidino arginine appeared in the peripheral circulation (33). Another assumption taken into account was a complete urinary recovery of $\left[{ }^{15} \mathrm{~N}\right]$ nitrate synthesized from $\mathrm{L}-\left[{ }^{15} \mathrm{~N}\right]_{2}$-guanidino arginine. However, Wagner et al. (34) reported urinary nitrate recoveries of approximately $60 \%$ after an oral administration of $\left[{ }^{15} \mathrm{~N}\right]$ nitrate. Therefore, several research groups have introduced a factor of 1.67 to correct for this inaccuracy $(18,32)$. However, we have not applied any adjustments to our estimates for several reasons: this correction factor was only based on urinary recoveries of $\left[{ }^{15} \mathrm{~N}\right]$ nitrate in adults. Second, Wagner et al. did not explore the oral bioavailability of $\left[{ }^{15} \mathrm{~N}\right]$ nitrate, and, finally, the urinary recovery of an oral dose of $\left[{ }^{15} \mathrm{~N}\right]$ nitrate would not necessarily reflect the handling and renal clearance of $\left[{ }^{15} \mathrm{~N}\right]$ nitrate originated from the systemic oxidation of $\mathrm{NO}$.
Our results showed reproducible measurements of wholebody NO synthesis in children over time periods of at least 2 wk apart. We discovered an ample range of percentage conversions of ${ }_{\mathrm{L}-}\left[{ }^{15} \mathrm{~N}\right]_{2}$-guanidino arginine to $\mathrm{NO}$ synthesis $(0.119 \%-0.411 \%)$. We considered that differences in renal function could explain this broad range of measurements. However, there was no correlation between renal creatinine clearance and 24-h urinary $\left[{ }^{15} \mathrm{~N}\right]$ nitrate excretion. Interestingly, we observed that whole-body NO synthesis was significantly higher in girls than in boys, which agrees with our previous observations of an enhanced NO biosynthesis in premenopausal healthy women $(29,31)$. However, multiple regression analysis showed age as the only predictor variable of whole-body NO synthesis, suggesting that normal aging modulates NO homeostasis in children. This finding agrees with other independent research groups who reported high levels of urinary nitrate excretion (index of NO synthesis) in infancy that declined with age (35-37). A similar age-related decrease was also observed in plasma $(6,37)$ and cerebrospinal fluid nitrate concentrations (38). Furthermore, analyzing the data presented in a previous study of convalescent, treated newborns with pulmonary hypertension (5), we observed a strong inverse correlation between age and percentage conversion of i.v. L- $\left[{ }^{15} \mathrm{~N}\right]_{2}$-guanidino arginine to urinary $\left[{ }^{15} \mathrm{~N}\right]$ nitrate $(r=-0.64)$. Further research with a larger sample size is required, however, to understand the functional significance of this association. It is conceivable or even hypothesized that this finding could be related to the natural increase of blood pressure observed in childhood.

This novel approach of measuring whole-body NO synthesis offers several advantages for studies with large populations of healthy and diseased children. First, it only requires a single oral administration of $\mathrm{L}-\left[{ }^{15} \mathrm{~N}\right]_{2}$-guanidino arginine, and urine collection on an ambulatory basis. In addition, the noninvasive and safe nature of this approach allows studies to be carried out in the field setting. Second, determination of percentage conversion of $\mathrm{L}_{-}\left[{ }^{15} \mathrm{~N}\right]_{2}$-guanidino arginine to urinary $\left[{ }^{15} \mathrm{~N}\right] \mathrm{ni}$ trate is independent of diet or any other exogenous source of $\left[{ }^{14} \mathrm{~N}\right]$ nitrate, which facilitates conduction of studies under more physiologic conditions. However, children should be maintained on a limited nitrate diet to achieve measurable urinary $\left[{ }^{15} \mathrm{~N}\right]$ nitrate enrichments in the range of $0.5 \%-1.2 \%$ with mass spectrometry. Third, our approach represents an improvement of the costly gas chromatography mass spectrometry $(18,32-34)$ by employing an isotope ratio mass spectrometer, which requires considerably less $\mathrm{L}_{-}\left[{ }^{15} \mathrm{~N}\right]_{2^{-}}$ guanidino arginine per subject (average cost: \$200). Furthermore, this mass spectrometer provides a sensitivity and precision of $\pm 0.0004 \%(22,23)$, which permits detection of differences of urinary $\left[{ }^{15} \mathrm{~N}\right]$ nitrate excretion at the low nanomolar concentration range. However, like other stable isotopic methodologies, this approach does not allow us to establish whether the source of synthesized $\left[{ }^{15} \mathrm{~N}\right]$ nitrate is from constitutive or inducible NOS. As children in this study were free of infection and trauma, we propose that the main source of urinary $\left[{ }^{15} \mathrm{~N}\right]$ nitrate reflected the activity of constitutive Larginine/NO pathway. 
In summary, the results of this study show for the first time that a single oral administration of $\mathrm{L}-\left[{ }^{15} \mathrm{~N}\right]_{2}$-guanidino arginine can be used to reliably and specifically determine whole-body NO synthesis in healthy children. Assessment of NO synthesis in children using this novel approach will provide important insights of the role of NO pathway in the pathophysiology, prognosis, and management of cardiovascular conditions and diseases characterized by an overproduction of NO such as septicemia (18), gastroenteritis (30), renal failure (39), inflammatory bowel disease, and asthma.

Acknowledgments. The authors are grateful to Dr. Yarwood (Oregon State University, Corvallis, OR) for his assistance with the mass spectrometry facilities.

\section{REFERENCES}

1. Moncada S, Higgs A 1993 The L-arginine-nitric oxide pathway. N Engl J Med 329:2002-2012

2. Forstermann U, Schmidt HH, Pollock JS, Sheng H, Mitchell JA, Warner TD, Nakane M, Murad F 1991 Isoforms of nitric oxide synthase. Characterization and purification from different cell types. Biochem Pharmacol 42:1849-1857

3. Nathan C, Xie QW 1994 Nitric oxide synthases: roles, tolls, and controls. Cell 78:915-918

4. Wyatt AW, Steinert JR, Mann GE 2004 Modulation of the L-arginine/nitric oxide signalling pathway in vascular endothelial cells. Biochem Soc Symp 71:143-156

5. Castillo L, DeRojas-Walker T, Yu YM, Sanchez M, Chapman TE, Shannon D, Tannenbaum S, Burke JF, Young VR 1995 Whole body arginine metabolism and nitric oxide synthesis in newborns with persistent pulmonary hypertension. Pediatr Res 38:17-24

6. Goonasekera CD, Shah V, Rees DD, Dillon MJ 1997 Nitric oxide activity in childhood hypertension. Arch Dis Child 77:11-16

7. Lopansri BK, Anstey NM, Weinberg JB, Stoddard GJ, Hobbs MR, Levesque MC, Mwaikambo ED, Granger DL 2003 Low plasma arginine concentrations in children with cerebral malaria and decreased nitric oxide production. Lancet 361:676-678

8. Duke T, South M, Stewart A 1997 Activation of the L-arginine nitric oxide pathway in severe sepsis. Arch Dis Child 76:203-209

9. Hegesh E, Shiloah J 1982 Blood nitrates and infantile methemoglobinemia. Clin Chim Acta 125:107-115

10. Forte P 2001 Plasma nitrate concentrations: a new diagnostic test in young infants with infectious gastroenteritis? J Pediatr Gastroenterol Nutr 32:418-420

11. Kharitonov SA, Yates D, Robbins RA, Logan-Sinclair R, Shinebourne EA, Barnes PJ 1994 Increased nitric oxide in exhaled air of asthmatic patients. Lancet 343:133135

12. Hoeldtke RD, Bryner KD, McNeill DR, Hobbs GR, Riggs JE, Warehime SS, Christie I, Ganser G, Van Dyke K 2002 Nitrosative stress, uric acid, and peripheral nerve function in early type 1 diabetes. Diabetes 51:2817-2825

13. Ljung T, Beijer E, Herulf M, Weitzberg E, Lundberg JO, Finkel Y, Hellstrom PM 2002 Increased rectal nitric oxide in children with active inflammatory bowel disease. J Pediatr Gastroenterol Nutr 34:302-306

14. Kissoon N, Duckworth L, Blake K, Murphy SP, Silkoff PE 1999 Exhaled nitric oxide measurements in childhood asthma: techniques and interpretation. Pediatr Pulmonol 28:282-296

15. Prasad A, Langford B, Stradling JR, Ho LP 2005 Exhaled nitric oxide as a screening tool for asthma in school children. Respir Med 100:167-173
16. Wennmalm A, Benthin G, Edlund A, Jungersten L, Kieler-Jensen N, Lundin S, Westfelt UN, Petersson AS, Waagstein F 1993 Metabolism and excretion of nitric oxide in humans. An experimental and clinical study. Circ Res 73:1121-1127

17. Archer S 1993 Measurement of nitric oxide in biological models. FASEB J 7:349-360

18. Argaman Z, Young VR, Noviski N, Castillo-Rosas L, Lu XM, Zurakowski D, Cooper M, Davison C, Tharakan JF, Ajami A, Castillo L 2003 Arginine and nitric oxide metabolism in critically ill septic pediatric patients. Crit Care Med 31:591-597

19. Marletta MA, Yoon PS, Iyengar R, Leaf CD, Wishnok JS 1998 Macrophage oxidation of L-arginine to nitrite and nitrate: nitric oxide is an intermediate. Biochemistry 27:8706-8711

20. White MF 1985 The transport of cationic amino acids across the plasma membrane of mammalian cells. Biochim Biophys Acta 822:355-374

21. Felig P, Wahren J 1971 Amino acid metabolism in exercising man. J Clin Invest 50:2703-2714

22. Forte P, Copland M, Smith LM, Milne E, Sutherland J, Benjamin N 1997 Basal nitric oxide synthesis in essential hypertension. Lancet 349:837-842

23. Forte P, Smith LM, Milne E, Benjamin N 1999 Measurement of nitric oxide synthesis in humans using L- $\left[{ }^{15} \mathrm{~N}_{2}\right.$ arginine. Methods Enzymol 301:92-98

24. Mosteller RD 1987 Simplified calculation of body-surface area. N Engl J Med 317:1098

25. Hauck RD, Melsted SW, Yankwich PE 1958 Use of N-isotope distribution in nitrogen gas in the study of dinitrification. Soil Sci 86:287-291

26. Bender DA, Bender AE 1997 Nutrition: A Reference Handbook. Oxford University Press, England, pp 60-68.

27. Bland JM, Altman DG 1986 Statistical methods for assessing agreement between two methods of clinical measurement. Lancet 1:307-310

28. British Standards Institution 1979 Precision of test methods, part 1: guide for the determination of repeatability and reproducibility for a standard test method. London, part 1, BS 5497

29. Forte P, Kneale BJ, Milne E, Chowienczyk PJ, Johnston A, Benjamin N, Ritter JM 1998 Evidence for a difference in nitric oxide biosynthesis between healthy women and men. Hypertension 32:730-734

30. Forte P, Dykhuizen RS, Milne E, McKenzie A, Smith CC, Benjamin N 1999 Nitric oxide synthesis in patients with infective gastroenteritis. Gut 45:355-361

31. O’Byrne S, Forte P, Roberts LJ 2nd, Morrow JD, Johnston A, Ängga ${ }^{\circ}$ rd E, Leslie RD, Benjamin N 2000 Nitric oxide synthesis and isoprostane production in subjects with type 1 diabetes and normal albumin excretion. Diabetes 49:857-862

32. Castillo L, deRojas TC, Chapman TE, Vogt J, Burke JF, Tannenbaum SR, Young VR 1993 Splanchnic metabolism of dietary arginine in relation to nitric oxide synthesis in normal adult man. Proc Natl Acad Sci U S A 90:193-197

33. Castillo L, Chapman TE, Yu YM, Ajami A, Burke JF, Young VR 1993 Dietary arginine uptake by the splanchnic region in adult humans. Am J Physiol 265:E532E539

34. Wagner DA, Schultz DS, Deen WM, Young VR, Tannenbaum SR 1983 Metabolic fate of an oral dose of ${ }^{15} \mathrm{~N}$-labeled nitrate in humans: effect of diet supplementation with ascorbic acid. Cancer Res 43:1921-1925

35. Tsukahara H, Hiraoka M, Hori C, Miyanomae T, Kikuchi K, Sudo M 1997 Age-related changes of urinary nitrite/nitrate excretion in normal children. Nephron 76:307-309

36. Anstey NM, Weinberg JB, Wang Z, Mwaikambo ED, Duffy PE, Granger DL 1999 Effects of age and parasitemia on nitric oxide production/leukocyte nitric oxide synthase type 2 expression in asymptomatic, malaria-exposed children. Am J Trop Med Hyg 61:253-258

37. Elli M, Soylemezoglu O, Erbas D, Bakkaloglu SA, Buyan N, Ozkaya O, Hasanoglu E 2005 Plasma and urine nitric oxide levels in healthy Turkish children. Pediat Nephrol 20:1605-1609

38. Clelland JD, Brand MP, Bolanos JP, Surtees RA, Land JM, Heales SJ 1996 Age dependent changes in the cerebrospinal fluid concentration of nitrite and nitrate. Ann Clin Biochem 33:71-72

39. Lau T, Owen W, Yu YM, Noviski N, Lyons J, Zurakowski D, Tsay R, Ajami A, Young VR, Castillo L 2000 Arginine, citrulline, and nitric oxide metabolism in end-stage renal disease patients. J Clin Invest 105:1217-1225 